\title{
KEPUASAN PERKAWINAN PADA PASANGAN MARRIED BY ACCIDENT
}

\author{
Marital Satisfaction on Married by Accident Couples \\ Maria Nona Nancy ${ }^{1}$, Maria Megaloma H. Gaharpung ${ }^{2}$, \\ Maria Himelta Astri Yuni \\ ${ }^{12}$ Program Studi Psikologi, Universitas Nusa Nipa
}

Diterima 29 September 2020 / Disetujui 30 Oktober 2020

\begin{abstract}
This study aims to determine marital satisfaction with couples married by accident. The research design used is quantitative research with a descriptive approach. The data collection method in this study is a quantitative method using a modified Likert scale. The scale used by the researcher is the marital satisfaction scale. Marriage satisfaction is measured based on aspects of marital satisfaction, namely Communication, Leisure Activity, Religious Orientation, Conflict Resolution, Financial Management, Sexual Orientation, Family and Friends, Children and Parenting, Personality Issues, and Equalitarian Role which consists of 16 valid items with a reliability of 0844. The sample in this study were 59 married couples with a background of married by accident in Maumere city with the research locations in the Alok Timur sub-district, Alok district and West Alok sub-district. The results showed that marital satisfaction with couples married by accident is classified as moderate
\end{abstract}

Keywords: marital satisfaction, married by accident

\begin{abstract}
ABSTRAK
Penelitian ini bertujuan untuk mengetahui kepuasan perkawinan pada pasangan married by accident. Rancangan penelitian yang digunakan adalah penelitian kuantitatif dengan pendekatan deskriptif. Metode pengumpulan data dalam penelitian ini adalah metode kuantitatif dengan menggunakan skala Likert modifikasi. Skala yang digunakan oleh peneliti adalah skala kepuasan perkawinan. Kepuasan perkawinan diukur berdasarkan aspek-aspek kepuasan perkawinan yaitu Communication, Leisure Activity, Religious Orientation, Conflict Resolution, Finansial Management, Sexual Orientation, Family and Friends, Children and Parenting, Personality Issues, dan Equalitarian Role yang terdiri dari 16 item valid dengan reliabilitas sebesar 0.844. Sampel dalam penelitian ini adalah 59 pasang suami istri dengan latar belakang married by accident di kota Maumere dengan lokasi penelitian di wilayah kecamatan kecamatan Alok Timur, kecamatan Alok dan kecamatan Alok Barat. Hasil penelitian menunjukkn bahwa kepuasan perkawinan pada pasangan married by accident tergolong sedang
\end{abstract}

Kata Kunci: kepuasan perkawinan, married by accident

\section{PENDAHULUAN}

Setiap individu dalam menyelesaikan tahap perkembangan dalam kehidupannya, akan masuk pada fase dewasa dan akan melaksanakan perkawinan. Perkawinan merupakan peristiwa penting dalam kehidupan seseorang. Hampir semua orang

\footnotetext{
*Korespondensi Penulis:

${ }^{1}$ nancykoseng2016@gmail.com,

${ }^{2}$ megagaharpung0530@gmail.com
}

mempunyai keinginan untuk menjalani hal tersebut. Perkawinan menunjukkan adanya ikatan lahir batin antara seorang suami dan seorang isteri dalam upaya membentuk keluarga. Keluarga yang terbentuk tanpa kematangan usia dan kesiapan dari segala arah, disebut married by accident. Married by accident merupakan fenomena yang marak terjadi saat ini.

Data menunjukan lebih dari 340 ribu pasangan usia anak menikah setiap tahunnya. Di Indonesia, data yang dirilis oleh UNICEF dan Badan Pusat Statistik 
Versi Online: http://journal.ubm.ac.id/index.php/psibernetika DOI: 10.30813/psibernetika.v13i2.2321

Hasil Penelitian

tahun 2016 menyebutkan bahwa anak perempuan pernah menikah pada usia 16-17 tahun. Data pengaduan anak korban pernikahan di bawah umur Komisi Perlindungan Anak Indonesia (KPAI) dalam 8 tahun terakhir sebanyak 95 kasus yang terlaporkan (www.KPAI.go.id). Sementara penulis meyakini data tersebut sangat banyak kejadian perkawinan yang disamarkan ditengah masyarakat. Berdasarkan hasil observasi, di Sikka pun banyak sekali terjadi kasus married by accident.

Married by accident yang terjadi merupakan suatu pernikahan yang dilakukan karena telah terjadi sesuatu terutama pihak perempuan dan umumnya telah terjadi kehamilan. Kehamilan sebelum menikah secara sah bukanlah hal yang diharapkan, sehingga membutuhkan solusi yaitu menikahkan pasangan.

Pada konteks suku Sikka yang berada di wilayah Flores Provinsi Nusa Tenggara Timur, sebuah perkawinan dinyatakan sah apabila telah melewati proses adat yang disebut belis secara penuh. Dalam proses belis, keluarga seorang pria melakukan utung omok (baca: gotong royong) dan akan memberikan kepada keluarga pihak wanita hasil dari utung omok tersebut biasanya berupa jarang (kuda), hoang-seng (Uang), bahar (emas) dan bala (gading). Proses ini biasanya dilaksanakan dalam beberapa tahap mulai dari poto surat, taser, poto wua Taa, tung gete, kela narang dan benjer kawit.

Pada prosesi perkawinan inilah terdapat sistem tukar menukar yang mempunyai daya pengikat dan daya gerak dari masyarakat di Sikka. Belis (mas kawin) dalam masyarakat Sikka tidak terlepas dari suatu sistim budaya yang berkaitan dengan adat istiadat dalam suatu perkawinan. Bagi masyarakat Sikka-Krowe, perkawinan merupakan suatu dorongan dasar untuk melanjutkan keturunan. Perkawinan merupakan wujud dorongan biologis yang realisasinya diatur sedemikian rupa dan ditradisikan turun temurun dalam adat istiadat masyarakat setempat. Urusan perkawinan antara pria
Jurnal Psibernetika

Vol.13 (No.2) : 59-67. Th. 2020

p-ISSN: 1979-3707

e-ISSN: 2581-0871

dan wanita merupakan pertalian yang tidak dapat dilepaskan. Hubungan yang menyatu itu terlukis dalam ungkapan Ea Daa Ribang, Nopok, Tinu daa koli tokar yang artinya pertalian kekerabatan antara kedua belah pihak akan berlangsung terus menerus dengan saling memberi dan menerima sampai kepada turun temurun. Norma-norma yang mengatur perkawinan ini dalam bahasa hukum adat yang disebut Naruk dua - moang dan kleteng latar yang tinggi nilai budayanya. Ungkapannya "Dua naha nora ling, nora weling, Loning dua utang ling labu weling, Dadi ata lai naha letto-wotter" artinya setiap wanita mempunyai nilai, mempunyai harga, sedangkan sarung dan bajunya juga mempunyai nilai dan harga, sehingga setiap lelaki harus membayar (Pareira, 1990)

Proses menikahkan seorang lakilaki dan perempuan pada suku Sikka ini terbilang panjang dan cukup rumit. Kami melalukan wawancara terhadap 3 kaum muda Sikka, dan tampak kaum muda saat ini merasakan belis sebagai beban yang harus ditanggung oleh mereka ketika kelak akan berumah tangga. Tuntutan besarnya belis yang kadang tak masuk akal justru membuat sebagian orang akhirnya melewati prosesi pernikahan yang singkat. Beberapa kaum muda di Sikka melakukan married by accident salah satunya dikarenakan tuntutan belis yang tergeser dari makna yang sesungguhnya. Hal tersebut bahkan dilakukan oleh mereka-mereka yang mengenyam pendidikan tinggi. Ada banyak pula pasangan tidak melaksanakan proses adat sama sekali tetapi memutuskan untuk hidup bersama karena telah terjadi sesuatu pada pihak perempuan (biasanya hamil) dan pihak perempuan akan menjalani satu tahap yang disebut plari depo. Plari depo adalah proses dimana seorang perempuan pergi ke rumah keluarga pihak laki-laki (yang menjadi pasangannya) untuk tinggal bersama suaminya tanpa sepengetahuan keluarga wanita.

Biasanya, keputusan hidup bersama oleh laki-laki dan perempuan ini akan menimbulkan konflik dalam kedua belah pihak keluarga. Tidak jarang banyak terjadi 
Versi Online: http://journal.ubm.ac.id/index.php/psibernetika DOI: 10.30813/psibernetika.v13i2.2321

Hasil Penelitian

perkelahian dan putus hubungan antara tua dan anak. Kondisi ini tentu saja memberikan pengaruh psikologis yang besar terutama kepada pasangan suami dan istri dan tentu saja berdampak pada rendahnya kualitas relasi dari pasangan tersebut.

Setiap pasangan yang menikah, tentunya mengharapakan kebahagiaan dalam perkawinan, sama halnya dengan pasangan yang menikah karena kecelakaan (married by accident). Meskipun pernikahan yang dilakukan tidak terencana, namun tentunya ada harapan dan keinginan dari pasangan tersebut untuk mengalami kebahagiaaan dan kepuasan dalam perkawinannya. Lestari (2012) mengatakan bahwa kepuasan perkawinan merupakan suatu perasaan positif yang dimiliki pasangan dalam perkawinan yang maknanya lebih luas dari pada kenikmatan, kesenangan, dan kesukaan.

Secara teoritis banyak faktor yang berpengaruh terhadap kepuasan perkawinan. Papalia et al. (2007) berpendapat bahwa faktor - faktor yang memengaruhi kepuasan perkawinan antara lain adalah (a) Usia saat menikah merupakan salah satu predikor utama. Orang yang menikah pada usia dua puluhan memiliki kesempatan lebih sukses dalam perkawinan, daripada yang menikah pada usia yang lebih muda, (b) Latar belakang pendidikan dan penghasilan, karena pendidikan dan penghasilan adalah saling berhubungan, mereka yang berpendidikan tinggi pada umumnya berpenghasilan lebih tinggi dan memiliki cara berpikir yang lebih terbuka. (c) Agama, dimana orang yang memandang agama sebagai hal yang penting, relatif jarang mengalami masalah perkawinan dibandingkan orang yang memandang agama sebagai hal yang tidak penting. (d) Dukungan emosional, kegagalan dalam perkawinan ini ada kemungkinan terjadi karena ketidakcocokan secara emosional dan tidak adanya dukungan emosional dari lingkungan, (e) Perbedaan harapan, dimana perempuan cenderung lebih mementingkan ekspresi emosional dalam pernikahan, disisi lain
Jurnal Psibernetika

Vol.13 (No.2) : 59-67. Th. 2020

p-ISSN: 1979-3707

e-ISSN: 2581-0871

suami cenderung puas jika istri mereka menyenangkan

Menurut Saxton (1986) untuk mencapai kepuasan perkawinan tersebut terdapat tiga kebutuhan yang juga menjadi aspek kepuasan perkawinan yang harus dipenuhi agar perkawinan memiliki kepuasan, yaitu kebutuhan materil (biologis), kebutuhan seksual, dan kebutuhan psikologis. Ketiga aspek tersebut saling berkaitan satu sama lain.

Olson \& DeFrain (2003) mengungkapkan bahwa Kepuasan dalam kebutuhan materil ditandai dengan adanya kepuasan fisik atau bilogis atas pemenuhan kebutuhan berupa makanan, tempat tinggal, keadaan rumah tangga yang teratur, dan uang. Kepuasan atas kebutuhan seksual ditandai dengan terpenuhinya kebutuhan seksual dengan adanya respon seksual yang baik dan frekuensi seksual yang tidak rendah, selain itu pasangan yang bahagia merasa lebih mendapatkan afeksi dibandingkan dengan pasangan yang kurang bahagia. Pasangan yang bahagia juga merasa bahwa pasangan mereka tidak akan menolak atau melakukan perilaku seksual yang kurang menyenangkan. Kebutuhan secara psikologis dapat dipenuhi dari persahabatan, keamanan emosional, saling memahami, menerima, menghormati, dan sependapat. Menurut Safarzadeh, dkk (2011), kepuasan perkawinan akan memberikan pengaruh kepada penilaian kebahagiaan individu dan merupakan kunci utama dalam suatu perkawinan. Ketika individu merasakan kebahagiaan dalam perkawinan maka akan tercipa kepuasan perkawinan. Pinsof dan Lebow (dalam Rini dan Retnaningsih, 2008:153) menyatakan bahwa kepuasan perkawinan merupakan suatu pengalaman subjektif, suatu perasaan yang berlaku dan suatu sikap, dimana semua itu didasarkan pada faktor dalam diri individu yang memengaruhi kualitas yang dirasakan dari interaksi dalam perkawinan.

\section{METODE PENELITIAN}

Penelitian yang digunakan adalah penelitian kuantitatif dengan pendekatan 
Versi Online: http://journal.ubm.ac.id/index.php/psibernetika DOI: 10.30813/psibernetika.v13i2.2321

Hasil Penelitian

deskriptif. Populasi dalam penelitian ini adalah pasangan dengan latar belakang Married by accident di kota Maumere. Sampel dalam penelitian ini adalah pasangan suami istri dengan latar belakang Married by accident di kota Maumere berjumlah 59 pasang dengan kriteria Sudah menikah secara sah, Usia perkawinan kurang dari 5 tahun, Bertempat tinggal di wilayah Kota Maumere yaitu di wilayah kecamatan Alok Timur, Alok dan Alok Barat., Pendidikan minimal SMA, Tinggal bersama dalam satu rumah.Pengukuran terhadap kepuasan perkawinan meggunakan skala kepuasan perkawinan yang dibuat menggunakan aspek-aspek kepuasan perkawinan yaitu:

a. Communication

Aspek ini melihat bagaimana perasaan dan sikap individu terhadap komunikasi dalam hubungan mereka sebagai suami istri seperti keterbukaan diantara pasangan (opennes), kejujuran terhadap pasangan (honesty), kemampuan untuk mempercayai satu sama lain (ability to trust), sikap empati terhadap pasangan (empathy) dan kemampuan menjadi pendengar yang baik (listening skill).

b. Leisure Activity

Aspek ini merefleksikan aktivitas sosial versus aktivitas personal, pilihan untuk saling berbagi antar individu, dan harapan dalam menghabiskan waktu senggang bersama pasangan.

c. Religious Orientation

Aspek ini mengukur makna kepercayaan agama dan prakteknya dalam pernikahan..

d. Conflict Resolution

Aspek ini mengukur persepsi pasangan mengenai eksistensi dan penyelesaian terhadap konflik dalam hubungan mereka..

\section{e. Finansial Management}

Aspek ini fokus pada bagaimana cara pasangan mengelola keuangan mereka.

\section{f. Sexual Orientation}

Aspek ini mengukur perasaan pasangan mengenai afeksi dan hubungan seksual mereka. Aspek ini menunjukan

\section{Jurnal Psibernetika \\ Vol.13 (No.2) : 59-67. Th. 2020 \\ p-ISSN: 1979-3707 \\ e-ISSN: 2581-0871}

sikap mengenai isu-isu seksual, perilaku seksual, kontrol kelahiran, dan kesetiaan.

g. Family and Friends

Aspek ini menunjukan perasaan dalam berhubungan dengan anggota keluarga dan keluarga dari pasangan, serta teman-teman, serta menunjukan harapan untuk mendapatkan kenyamanan dalam menghabiskan waktu bersama keluarga dan teman-teman.

h. Children and Parenting

Aspek ini mengukur sikap dan perasaan terhadap tugas mengasuh dan membesarkan anak. Aspek ini fokus pada keputusan-keputusan yang berhubungan dengan disiplin, masa depan anak dan pengaruh anak terhadap hubungan pasangan.

\section{i. Personality Issues}

Aspek ini mengukur persepsi individu mengenai pasangan mereka dalam menghargai perilaku-perilaku dan tingkat kepuasan yang dirasakan terhadap masalah mengenai kepribadian masing-masing.

\section{j. Equalitarian Role}

Aspek ini mengukur perasaan dan sikap individu mengenai peran pernikahan dan keluarga.

Analisis data dilakukan menggunakan analisis deksriptif. Untuk membuat kategori dilakukan dengan rumus:

$$
\begin{gathered}
\text { Tinggi: } \mathbf{X}>\text { Mean }+ \text { SD } \\
\text { Sedang: Mean-SD } \leq \mathbf{X} \leq \text { Mean+SD } \\
\text { Rendah: } \mathbf{X}<\text { Mean-SD }
\end{gathered}
$$

\section{HASIL DAN PEMBAHASAN}

\section{Analisis deskriptif kepuasan perkawinan pasangan}

Data hasil penelitian berdasarkan jawaban skala yang telah dikerjakan mendapatkan hasil, skor tertinggi 64 dan skor terendah 33. Skor rata-rata kepuasan perkawinan pada suami 50.65 dan standar deviasi 6.56. Uraian dari variabel disajikan dalam tabel klasifikasi yang terdiri dari tiga kategori yaitu sebagai berikut: 
Versi Online: http://journal.ubm.ac.id/index.php/psibernetika DOI: 10.30813/psibernetika.v13i2.2321

Hasil Penelitian

Tabel 1. Deskripsi kepuasan pernikahan

\begin{tabular}{cccc}
\hline Kriteria & f & $\%$ & Kategori \\
\hline $57,21 \leq \mathrm{X}$ & 8 & 6,67 & Tinggi \\
$44,09 \leq \mathrm{X}<$ & 90 & 75 & Sedang \\
57,21 & & & \\
$\mathrm{X}<44,09$ & 22 & 18,33 & Rendah \\
\hline Total & 120 & $100 \%$ & \\
\hline
\end{tabular}

Berdasarkan tabel di atas dapat diketahui bahwa skor terbanyak ada pada rentangan skor 44,09 $\leq X<57,21$ sebanyak 90 orang atau $75 \%$ dan ada pada kategori sedang, urutan kedua ada pada rentangan skor $X<44,09$ sebanyak 22 orang atau $18,33 \%$ berada pada kategori rendah, urutan ketiga pada kategori tinggi pada rentangan angka $57,21 \leq \mathrm{X}$ sebanyak 8 orang atau 6,67\%. Dengan demikian dapat disimpulkan bahwa kepuasan perkawinan pada pasangan married by accident pada umumnya sedang, yaitu mencapai angka $74,58 \%$

\section{Analisis Deskriptif kepuasan perkawinan istri}

Data hasil penelitian berdasarkan jawaban skala yang telah dikerjakan mendapatkan hasil, skor tertinggi 64 dan skor terendah 33. Skor rata-rata kepuasan perkawinan pada istri 50,11 dan standar deviasi 6,05. Uraian dari variabel disajikan dalam tabel klasifikasi yang terdiri dari tiga kategori yaitu sebagai berikut:

Tabel 2. Kepuasan pernikahan istri

\begin{tabular}{lccc}
\hline Kriteria & f & \% & Kategori \\
\hline $56,16 \leq \mathrm{X}$ & 5 & 8,33 & Tinggi \\
$44,06 \leq \mathrm{X}$ & 45 & 75 & Sedang \\
$<56,16$ & & & \\
$\mathrm{X}<44,06$ & 10 & 16,67 & Rendah \\
\hline Total & 60 & $100 \%$ & \\
\hline
\end{tabular}

Berdasarkan tabel di atas dapat diketahui bahwa skor terbanyak ada pada rentangan skor 44,06 $\leq X<56,16$ sebanyak
Jurnal Psibernetika

Vol.13 (No.2) : 59-67. Th. 2020

p-ISSN: 1979-3707

e-ISSN: 2581-0871

45 orang atau $75 \%$ dan ada pada kategori sedang. Dengan demikian dapat disimpulkan bahwa kepuasan perkawinan istri married by accident pada umumnya berada pada kategori sedang.

\section{Analisis Deskriptif kepuasan perkawinan suami}

Data hasil penelitian berdasarkan jawaban skala yang telah dikerjakan mendapatkan hasil, skor tertinggi 64 dan skor terendah 37. Skor rata-rata kepuasan perkawinan pada suami 50,98 dan standar deviasi 7,04. Uraian dari variabel disajikan dalam tabel klasifikasi yang terdiri dari tiga kategori yaitu sebagai berikut:

\begin{tabular}{lccc}
\hline Kriteria & f & $\%$ & Kategori \\
\hline $58,02 \leq X$ & 7 & 11,67 & Tinggi \\
$43,94 \leq X<$ & 45 & 75 & Sedang \\
58,02 & & & \\
$X<43,94$ & 8 & 13,33 & Rendah \\
\hline Total & 60 & $100 \%$ & \\
\hline
\end{tabular}

Berdasarkan tabel di atas dapat diketahui bahwa skor terbanyak ada pada rentangan skor 43,94 $\leq X<58,02$ sebanyak 45 orang atau $75 \%$ dan ada pada kategori sedang. Dengan demikian dapat disimpulkan bahwa kepuasan perkawinan suami married by accident pada umumnya berada pada kategori sedang.

\section{Uji Beda kepuasan Perkawinan berdasarkan tingkat pendidikan}

Berdasarkan pengujian, diketahui bahwa terdapat perbedaan yang signifikan berdasarkan tingkat pendidikan dengan mean difference sebesar 3, 228 dimana mereka yang memiliki tingkat pendidikan sekolah menengah lebih rendah kepuasan perkawinan jika dibandingkan dengan mereka yang mengenyam pendidikan tinggi. Mean pendidikan menengah sebesar 49,95 sedangkan mean pendidikan tinggi sebesar 53,18 
Versi Online: http://journal.ubm.ac.id/index.php/psibernetika DOI: 10.30813/psibernetika.v13i2.2321

Hasil Penelitian

\section{Uji beda Kepuasan Perkawinan berdasarkan tempat tinggal}

Berdasarkan pengujian, diketahui bahwa terdapat perbedaan yang signifikan berdasarkan tingkat pendidikan dengan mean difference sebesar 4,69 dimana mereka yang tinggal bersama orang tua lebih rendah kepuasan perkawinan jika dibandingkan dengan mereka yang tinggal sendiri.

Penelitian ini menemukan bahwa kepuasan perkawinan pada psangan married by accident tergolong sedang yaitu mencapai $75 \%$. Hal ini dapat dijelaskan bahwa baik suami maupun istri sama-sama menyadari bahwa kepuasan perkawinan adalah sesuatu yang penting dan harus diperjuangkan bersama melalui penyesuaian dalam perkawinan. Senada dengan pendapat yang dikemukakan oleh Rachmawati (2013:75), bahwa kepuasan perkawinan dapat dicapai melalui penyesuaian perkawinan. Penyesuaian perkawinan itu sendiri adalah suatu sikap bertoleransi antara individu dengan pasangannya yang masing-masing harus rela berkorban dari kepentingan pribadi untuk kepentingan bersama. Dengan demikian, ketika pasangan suami istri membangun sikap toleransi dan rela berkorban di dalam kehidpuan perkawinannya maka pasangan tersebut dapat menyesuaikan diri dan akan mencapai kepuasan perkawinan. Pada pasangan married by ccident, situasi yang dirasakan agak berbeda dengan pasangan lain yang menikah secara terencana. Dalam budaya sikka, pasangan yang menikah tidak sesuai dengan prosesi adat biasanya akan mendapatkan sanksi sosial. Masyarakat sekitar akan membicarakan sisi negatif pasangan tersebut. kondisi ini sangat memungkinkan terjadinya konflik dalam perkawinan karena membutuhkan penyesuaian yang lebih dari kedua belah pihak. Selain menyesuaikan diri dengan pasangan dan keluarga, pasangan juga perlu menyesuaikan diri secara sosial. Secara sosial, biasanya seorang perempuan (istri) membutuhkan waktu yang lama untk dapat

\section{Jurnal Psibernetika \\ Vol.13 (No.2) : 59-67. Th. 2020 \\ p-ISSN: 1979-3707 \\ e-ISSN: 2581-0871}

berbaur dengan masyarakat sekitar. pada awal hidup bersama, seorang perempuan (istri) akan jarang keluar rumah karena malu dengan stigma yang secara sosial disematkan kepadanya.

Menurut Macdonald (2007), selama tahun pertama dan kedua perkawinan pasangan suami istri biasanya harus melakukan penyesuaian utama satu sama lain, terhadap anggota keluarga masing masing, dan teman - temannya. Pada proses penyesuaian, sering timbul ketegangan emosional dan khususnya terjadi pada keluarga muda. Penyesuaian perkawinan banyak dipengaruhi oleh beberapa faktor, salah satunya adalah kesamaan latar belakang. Hal - hal yang menjadi kesamaan latar belakang tersebut antara lain pendidikan, budaya atau ras, agama, status sosial, minat, dan lain sebagainya. Kualitas dalam perkawinan dapat memengaruhi berlangsungnya proses-proses lain dalam keluarga, misalnya pengasuhan dan performansi individu (Richard, Forehand, Atkeson \& Lopez, 1982). Mengingat pentingnya kepuasan perkawinan, pasangan didorong untuk mengembangkan aspekaspek yang dapat meningkatkan kepuasan perkawinan agar dapat mewujudkan keluarga yang bahagia dan generasi yang berkualitas.

Jika diuji secara terpisah maka baik suami maupun istri merasakan kepuasan perkawinan dapa aktegori sedang yaitu sebesar $75 \%$. kepuasan perkawinan bersifat individual. Tiap individu yang dapat mengendalikan emosinya dengan baik dapat mendatangkan kebahagiaan bagi dirinya. Hal tersebut dapat diartikan semakin baik kemampuan pasangan suami istri dalam meregulasi emosinya, maka semakin tinggi juga kepuasan akan pernikahan yang mereka jalani, sebaliknya jika kemampuan meregulasi emosinya kurang baik, maka kepuasan akan pernikahan yang dijalaninya juga rendah. Kemampuan meregulasi emosi merupakan salah satu faktor yang dapat mempengaruhi kepuasan pada pernikahan yang dijalani, sehingga dituntut kepada setiap pasangan suami istri untuk dapat memiliki kemampuan meregulasi emosinya 
Versi Online: http://journal.ubm.ac.id/index.php/psibernetika DOI: 10.30813/psibernetika.v13i2.2321

Hasil Penelitian

dengan baik untuk mencapai kepuasan pada pernikahannya, terutama pada pernikahan yang masih pada fase awal, yaitu satu sampai lima tahun di mana masa itu merupakan masa adaptasi dari masingmasing pasangan terhadap pasangannya (Wulan \& Chotimah, 2017:62).

\section{Pembahasan}

Ketika pasangan dapat menyesuaikan diri satu sama lain maka akan mencapai kepuasan dalam perkawinan. Dari penelitian ini juga dapat diketahui bahwa meskipun hasil penelitian mengungkapkan bahwa kepuasan perkawinan, pada umumnya sedang namun ada beberapa pasangan yang kepuasan perkawinan berada pada ketegori rendah kategori kepuasan perkawinan rendah yaitu pada istri sebanyak $16,67 \%$ dan pada suami sebanyak $13,33 \%$. Hal ini dapat dijelaskan bahwa perkawinan merupakan penyatuan dua individu dengan kepribadian yang berbeda, latar belaakang yang berbeda dan pola pikir yang berbeda sehingga di butuhkan penyesuaian satu dengan yang lain. Dalam sebuah penelitian yang dilakukan oleh Lavee \& Ben-Ari (dalam papalia, dkk, 2009, 197) menjelaskan bahwa kecenderungan ke arah ketidakstabilan emosional dan negativitas baik pada suami maupun istri merupakn peramal kuat ketidakbahagiaan pernikahan. Salah satu faktor tidak menonjol yang mendasari konflik dan kegagalan pernikahan adalah perbedaan dalam apa yang diharapkan perempuan dan laki-laki dalam pernikahan. Perempuan cenderung lebih mementingkan keekspresifan emosional yaitu ekpresi mereka dan suami daripada laki-laki. Istri juga cenderung memperpanjang diskusi suatu masalah dan menunjukkan kekesalahan bila suami menyerang balik atau menghindari tanggung jawab mereka dalam pertengkaran. Suami, di didi lain, cenderung puas bila istri mereka cukup ingin "berbaikan" ( Fincham, Beach dan Davila, 2004)

Selain itu, kurangnya komunikasi antara satu dengan yang lain hingga

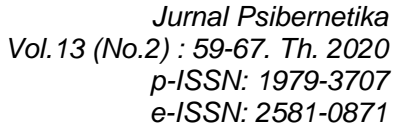

frekuensi waktu luang bersama yang kurang membuat hubungan antara suami dan istri menjadi tidak berkualitas. Olson \& Olson (2000) menyatakan bahwa komunikasi merupakan aspek yang paling penting karena berkaitan dengan hampir semua aspek dalam hubungan pasangan. Temuan berdasarkan jawaban dalam aspek komunikasi menunjukan rendahnya kualitas komunikasi pasangan. Kesalahan dalam komunikasi tentu dapat menimbulkan konflik. Lestari (2018) menjelaskan bahwa biasanya gaya komunikasi negatif sering menimbulkan konflik pada pasangan karena menggunakan pernyataan "Kamu". Dengan demikian pihak yang menerima pesan akan merasa dituduh melakukan sesuatu. Melalui proses komunikasi semua perbedaan pandangan dapat diselesaikan dengan baik. Komunikasi dapat menjembatani jarak emosional yang jauh antar pasangan suami istri menjadi dekat dan intim, sekaligus meruntuhkan benteng perbedaan yang menjadi sekat pemisah yang menghalangi terciptanya keintiman perkawinan yang menyebabkan pasangan tidak dapat memilki perasaan bersyukur karena tidak daat menerima kenyataan yang dialaminya sehingga kepuasan perkawinan menjadi rendah.

Hasil penelitian juga menemukan bahwa terdapat perbedaan kepuasan perkawinan dari tingkat pendidikan. Newman dan Newman (Carr, 2004 : 257) berpendapat bahwa prediktor dari sukses atau gagalnya perkawinan dilihat dari faktor sosial atau faktor demografik seperti pendapatan, pendidikan, usia pernikahan, perbedaan usia antara suami istri dan kompatibilitas seksual. pasangan yang memiliki tingkat pendidikan yang rendah, dapat merasakan kepuasan yang lebih rendah karena lebih banyak menghadapi stressor seperti pengangguran atau tingkat penghasilan rendah. Temuan lainnya adalah, terdapat perbedaan kepuasan perkawinan berdasarkan tempat tinggal dimana pasangan yang tinggal sendiri lebih puas dibanding pasangan yang tinggal bersama orang tua. Dalam budaya Sikka, sistem " extended Family" masih sangat 
Versi Online: http://journal.ubm.ac.id/index.php/psibernetika DOI: 10.30813/psibernetika.v13i2.2321

Hasil Penelitian

kuat dianut oleh pasangan. Tinggal bersama mertua dan ipar adalah hal yang lumrah dan dilakukan oleh banyak pasangan. Di Indonesia, mertua merupakan tokoh kerabat terpenting dan bersifat resmi bagi pasangan. Koentrajaningrat (1984) menjelaskan bahwa apabila seorang istri tinggal di rumah pihak suami maka kemungkinan timbulnya persengketaan dengan mertua lebih besar karena bentrokan antar keduanya biasanya berkaitan dengan masalah rumah tangga. Williams, Sawyer, \& Wahlstorm (2006) menjelaskan bahwa seiring waktu kebersamaan yang terjalin, dengan pihak dari masing-masing pasanganseperti mertua dan Ipar turut memengaruhi kepuasan perkawinan. Hurlock (1980) mengungkapkan bahwa sangat penting bagi pasangan suami istri melakukan penyesuaian dengan keluarga barunya termasuk mertua dan ipar. Penyesuaian ini dilakukan karena danya perbedaan latar belakang budaya, minat dan usia sehingga pasangan suami istri belajar untuk memahami mereka.

\section{SIMPULAN DAN SARAN}

Penelitian ini menemukan bahwa kepuasan perkawinan pada psangan married by accident tergolong sedang yaitu mencapai $75 \%$.

Saran bagi seluruh pasangan suami istri yaitu kepuasan perkawinan yang dirasakan subjek penelitian dapat dipertahankan dan ditingkatkan. Hal ini dilakukan dengan mengontrol dirinya sendiri sehingga subjek dapat berpikir lebih positif dan terhindar dari pikiran negatif. Selain itu bagi pasangan suami-isteri yang memiliki kepuasan perkawinan yang tergolong rendah sedapat mungkin bisa menyelesaikan masalah yang dihadapi secara bersama-sama sehingga akan membantu untuk mencapai pemenuhan kebutuhan yang diinginkan dalam kehidupan perkawinan.

Saran bagi pemuda-pemudi adalah mempersiapkan pernikahan secara baik dan terencana sehingga meminimalisir terjadinya konflik dalam perkawinan. Saran bagi penasehat perkawinan hendaknya
Jurnal Psibernetika

Vol.13 (No.2) : 59-67. Th. 2020

p-ISSN: 1979-3707

e-ISSN: 2581-0871

menggunakan kebersyukuran, pemaafan sebagai media atau terapi untuk memperbaiki hubungan suami-istri yang bermasalah dan menyarakan kepada pasangan agar lebih mempererat hubungan yang intim antara satu dengan yang lain.

Saran bagi peneliti selanjutnya yang tertarik untuk melakukan penelitian dengan tema yang sama diharapkan dapat menambah variabel penelitian, memperluas variabel penelitian dan menyempurnakan alat ukur sehingga dapat menjadi sumbangan informasi penelitian di bidang psikologi.

\section{DAFTAR PUSTAKA}

Badan Pusat Statistik (BPS). 2018. Kapubaten Sikka dalam Angka. Maumere: BPS Kabupaten Sikka.

Carr, A. 2004. Positive Psychology : The Science of Happiness and Human Strengths. New York : Brunner Routledge

Fincham, F. D; Beach, S. H \& Davila. 2004. Forgiveness and Conflict Resolution in Marriage. Journal of Family Psychology, 18, 72-81

Hurlock, E. B. 1980. Psikologi Perkembangan: Suatu Pendekatan Sepanjang Rentang Kehidupan. Jakarta: Erlangga

Kunaszuk, R. M. E. Thesis. Intimaci, Libido, Depressive Symptoms and Marital Satisfaction in Postpartum Couples. Drexel University.

Lestari,S.,2012. Psikologi Keluarga: Penanaman Nilai dan Penanganan Konflik dalam Keluarga. Jakarta: Kencana Prenada Media Group

Macdonald, A.J. 2007. Solution-Focused Therapy : Theory, Research and Practice. Los Angeles : Sage Publications

Monks, F.J. dan Knoers, A.M.P. dan Haditono, S.R., 2006. Psikologi Perkembangan : Pengantar dalam Berbagai Bagiannya. Yogyakarta : Gadjah Mada University Press. 
Versi Online: http://journal.ubm.ac.id/index.php/psibernetika DOI: 10.30813/psibernetika.v13i2.2321

Hasil Penelitian

Olson, D.H., \& De Frain, J. (2003). Marriage and families, intimacy, diversity, and strengths, Fourth Edition. Boston: McGraw-Hill.

Olson, D. H \& Olson, A. K. 2000. Empowering Couples: Building on Your Strengths. Minneapolis, MN: Life Innovation, Inc.

Papalia, D.E. and Olds, S.W. and Feldman, R.D., 2007. Human development. Tenth Edition. New York : McGraw - Hill International Edition.

Rahmawati, D \& Mastutu, E. 2013. Perbedaan Tingkat Keuasan Perkawinan Ditinjau dari Tingkat Penyesuaian Perkawinan pada Istri Brigif 1 Marinir TNI - AL yang Menjalani Long Distance Marriage. Jurnal Psikologi Pendidikan dan Perkembangan. Vol.2, No.02.

Rini, Q.K., \& Retnaningsih. (2008). Keterbukaan diri dan kepuasan perkawinan pada pria dewasa awal. Jurnal Psikologi. Volume 1 No. 2 pp. 152-157.

Safarzade, S., Esfahaniasl, M., \& Bayat, M. R. (2011). The relationship between forgiveness, perfectionism and intimacy and marital satisfaction in
Jurnal Psibernetika Vol. 13 (No.2) : 59-67. Th. 2020 p-ISSN: 1979-3707 e-ISSN: 2581-0871

Ahwaz Islamic Azad University married students. Middle-East Journal of Scientific Research, 9(6), 778-784.

Subekti, Trusto. 2010. Sahnya Perkawinan Menurut Undang-undang Nomor 1 Tahun 1974 Tentang Perkawinan Ditinjau dari Hukum Perjanjian. Jurnal Dinamika Hukum. Vol. 10, No. 3, 329-338

Saxton,L. (1986). The individual, marriage, and the family. California: Wadsworth Publishing Company.

Sugiyono. (2013). Statistika untuk peneliti. Bandung: Alfabeta.

Schaefer, M. T. and Olson, D. H. 1981. Assessing intimacy: the pair inventory. Journal of Marital and Family Therapy. Minnesota : University of Minnesota.

Williams, Brian, K; Sawyer, Stacey C., Wahlstorm, Carl M. (2006). Marriages, families, and intimate relationships: a practical introduction. Boston: Pearson Education Inc 